\title{
Solution to best food reference material challenge
}

\section{Melissa Phillips ${ }^{1}$}

Published online: 13 September 2018

(C) Springer-Verlag GmbH Germany, part of Springer Nature 2018

\section{Solution}

Although there is no "correct" answer to the Best Food Reference Material Challenge [1], some options do exist that will provide Sally with an acceptable reference material for her analysis of fortified calcium and vitamin $\mathrm{D}_{3}$ in a meat-containing Italian pasta sauce product.

First, the profile of the pasta sauce must be normalized for placement in the food triangle and comparison to profiles of existing reference materials (see Table below).

\begin{tabular}{|l|c|c|}
\hline & $\begin{array}{c}\text { Mass per } \\
\text { Serving (g) }\end{array}$ & $\begin{array}{c}\text { Fraction of } \\
\text { Total (\%) }\end{array}$ \\
\hline Fat & 3 & 17 \\
\hline Protein & 2 & 11 \\
\hline Carbohydrate & 13 & 72 \\
\hline Total & 18 & 100 \\
\hline
\end{tabular}

This profile of nutrients corresponds to Sector 5 of the AOAC Food Triangle, as shown below in red. Because numerous reference materials have been characterized for calcium content, Sally should begin her search for a reference material with an assigned value for vitamin $\mathrm{D}_{3}$.

This article is the solution to the Analytical Challenge to be found at https://doi.org/10.1007/s002016-018-0871-7

Melissa Phillips

melissa.phillips@nist.gov

1 National Institute of Standards \& Technology, Gaithersburg, MD, USA

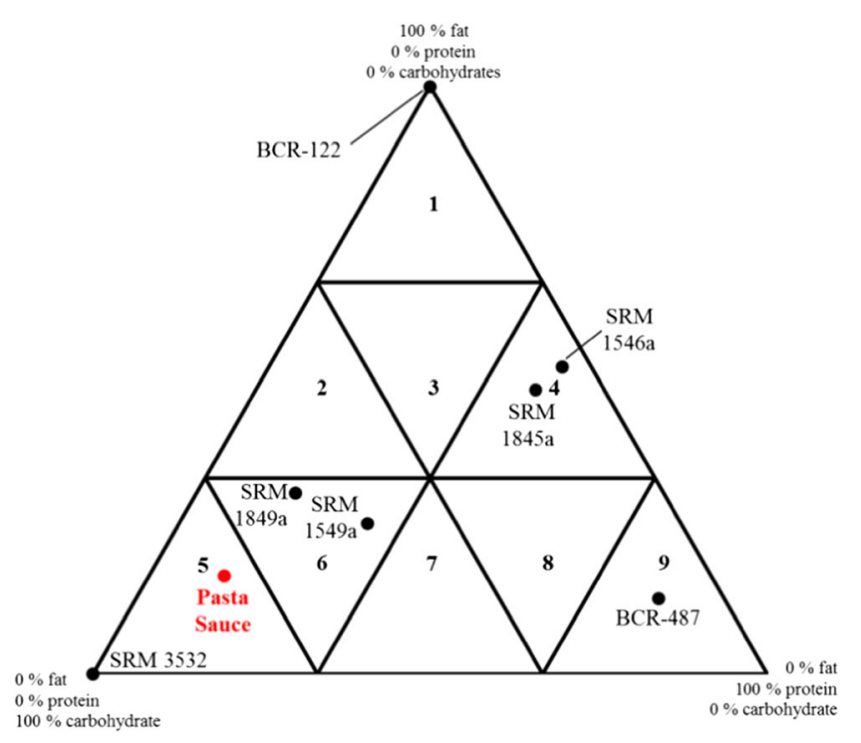

An internet search indicates that only two providers of Certified Reference Materials (CRMs) have food materials with assigned values for vitamin $\mathrm{D}_{3}$ : the United States National Institute of Standards and Technology and the European Commission Joint Research Centre. The seven materials that are available from these two providers are plotted on the Food Triangle for comparison with the location of the test sample (pasta sauce). The reference materials in closest proximity to the test sample are SRM 1549a Whole Milk Powder, SRM 1849a Infant/Adult Nutritional Formula, and SRM 3532 Calcium-Containing Solid Oral Dosage Form. All three of these materials also have assigned values for calcium, and therefore could be appropriate reference materials for Sally's analysis. However, the levels of vitamin $\mathrm{D}_{3}$ and calcium in SRM 1549a are endogenous, and may be more difficult to extract or digest from the matrix than Sally's test sample. Therefore, SRM 1849a and SRM 3532 both represent 
possible reference materials for Sally. To make the best decision about which material to use, Sally should first compare the mass fractions of the nutrients in her sample to those in the reference materials. For example, the vitamin $\mathrm{D}_{3}$ level in SRM $3532(1.3 \mathrm{mg} / \mathrm{kg})$ is over 10 times higher than that in SRM 1849a $(0.11 \mathrm{mg} / \mathrm{kg})$, and the level of calcium in SRM 3532 $(175 \mathrm{mg} / \mathrm{g})$ is 35 times higher than that in SRM 1849a (5.3 $\mathrm{mg} / \mathrm{g}$ ). Appropriately matching the levels of the nutrients in the sample and reference material will reduce the possibility of extraction differences based on concentration and allows both the sample and reference material to be treated identically prior to analysis and with respect to calibration.

Lastly, Sally may want to consider the price of CRMs in her decision! Although the two materials are very similar in price (see Table below), a unit of SRM 1849a will offer twice the amount of material. That said, however, because the levels of vitamin $\mathrm{D}_{3}$ and calcium are higher in SRM 3532, significantly less material will be required for each analysis.

\begin{tabular}{|l|c|c|c|c|c|}
\hline \multirow{2}{*}{ CRM } & \multirow{2}{*}{ Unit Size } & \multirow{2}{*}{ Total Mass } & \multicolumn{2}{|c|}{$\begin{array}{c}\text { Relative Quantity Needed for } \\
\text { Analysis of the Pasta Sauce }\end{array}$} & \multirow{2}{*}{ Unit Price } \\
\cline { 4 - 5 } & & & Vitamin $\mathrm{D}_{3}$ & Calcium & \\
\hline SRM 1849a & $10 \times 10 \mathrm{~g}$ & $100 \mathrm{~g}$ & $10 \mathrm{x}$ & $35 \mathrm{x}$ & 782 USD \\
\hline SRM 3532 & $5 \times 10 \mathrm{~g}$ & $50 \mathrm{~g}$ & $1 \mathrm{x}$ & $1 \mathrm{x}$ & 867 USD \\
\hline
\end{tabular}

Given all of these factors, and the expected levels of vitamin $\mathrm{D}_{3}$ and calcium in a meat-containing Italian pasta sauce product, I would recommend SRM 1849a Infant/ Adult Nutritional Formula as the best reference material for Sally's analysis. While not intuitive, the consideration of the fat, protein, and carbohydrate profile of the material, the desired nutrients, and their levels and fortification indicate that SRM 1849a is the best match from available reference materials.

\section{Reference}

1. Phillips M. Best food reference material challenge. Anal Bioanal Chem. 2018;410:2451-2. 